\title{
Assessment of the State of Onobrychis tavernierfolia Stocks ex Boiss.(Fabaceae) Cenopopulations Southwestern Kyzylkum(Uzbekistan)
}

\author{
Habibullo F. Shomurodov', Ozodbek S. Abduraimov', Rizamat Sh. Khayitov², \\ Shakhnoza U. Saribaeva ${ }^{1}$ \\ ${ }^{1}$ Institute of Botany Academy Sciences Republic of Uzbekistan, Tashkent, Uzbekistan \\ ${ }^{2}$ Navoi State Pedagogical Institute, Navoi, Uzbekistan \\ Email: ozodbek88@bk.ru
}

How to cite this paper: Shomurodov, H.F., Abduraimov, O.S., Khayitov, R.Sh. and Saribaeva, S.U. (2021) Assessment of the State of Onobrychis tavernierfolia Stocks ex Boiss.(Fabaceae) Cenopopulations Southwestern Kyzylkum(Uzbekistan). American Journal of Plant Sciences, 12, 1043-1050. https://doi.org/10.4236/ajps.2021.127072

Received: June 3, 2021

Accepted: July 17, 2021

Published: July 20, 2021

Copyright $\odot 2021$ by author(s) and Scientific Research Publishing Inc. This work is licensed under the Creative Commons Attribution International License (CC BY 4.0).

http://creativecommons.org/licenses/by/4.0/

\begin{abstract}
In the period 2019-2021, two coenotic populations of $O$. tavernierfolia were studied in different ecological and phytocenotic conditions of relic mountain Kuldzhuktau. Very rare species of the Kyzylkum. It is spread at the Kyzylkum: the Kuldzhuktau, near Ayak-Guzhumdy and Churuk (Bukhara region). Inhabits stony and gypseous slopes. There are three small populations can be found. Limiting factors: degradation of habitat as a result of overgrazing. Measures of protection: not protected. The article is devoted to the assessment of the current state of coenotic populations of the rarest southwestern Kyzylkum (Kuldzhuktau) Onobrychis tavernierfolia. It was found that the studied coenopopulations of $O$. tavernierfolia are normal and complete.
\end{abstract}

\section{Keywords}

Onobrychis Tavernierfolia, Cenopopulation, Kyzylkum, Assessment, Rare Plant, Population Signs

\section{Introduction}

Currently, population analysis methods are a reliable way to diagnose the conditions of populations of different plant species in natural and artificial communities. In addition, this set of methods provides the researcher with a departure from subjective visual assessments of the state of plants and plant communities by applying accurate quantitative accounting that reflects the internal plasticity 
and variability of plants.

Genus Onobrychis Mill it belongs to the tribe Hedysareae, the subfamily Faboidea, which is part of one of the largest families of flowering plants-Fabaceae, order Fabales. In the modern flora, the genus is represented by 170 species, which are widely distributed in the triangle of Anatolia-Iran-Caucasus.

The assessment of the state of the coenopopulation of $O$. tavernierfolia remains poorly understood. Onobrychis tavernierfolia Stocks ex Boiss. (Fabaceae)-a very rare and small annual plant of Kyzylkum desert (part Uzbekistan). One of the rare red book species with a disjunctive range from Central Kyzylkum to Central Iran, a remarkable ephemer-Onobrychis taevernierifolia is a new and very promising phytomeliorant. It is included in the "Red Book of the Republic of Uzbekistan" with the status 1 [1]. The purpose of this work is to study the state of the coenopopulations of Onobrychis taevernierifolia in southwestern Kyzylkumi (Kuldzhuktau).

\section{Material and Methods}

In the period 2019-2021, two coenotic populations of $O$. tavernierfolia were studied in different ecological-phytocenotic conditions of relic mountain Kuldzhuktau (Figure 1).

Geobotanical descriptions were performed according to the standard method at sites of $100 \mathrm{~m}$ [2].

According to the allocation characteristics of desert species, it was studied according to the method of M. V. Markov [3]. The relationship between the size of the reproductive force and the life form was studied. Eight features of the allocation characteristic were analyzed: the number of seeds per individual, the total mass of one individual, the mass of roots, the mass of the aboveground vegetative part, the mass of the generative part, the mass of one seed, the height of the

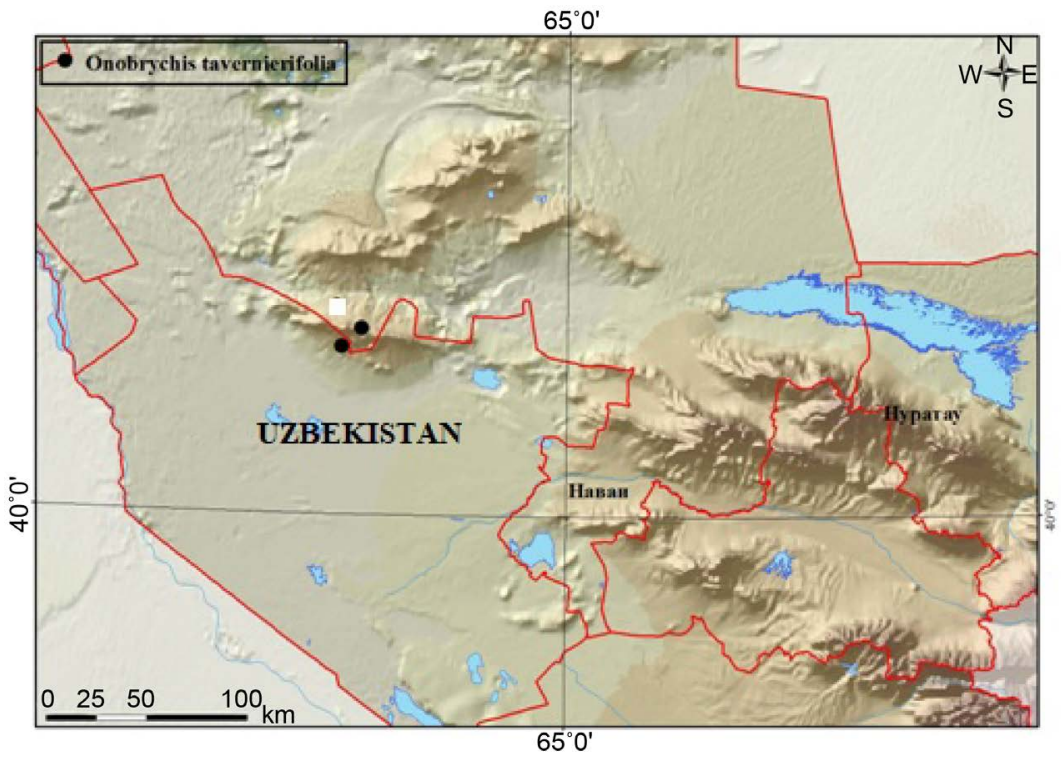

Figure 1. Distribution maps of Onobrychis tavernierifolia. 
aboveground part, the length of the roots, and the vector spectrum was constructed. Additionally, the density of $O$. tavernierifolia individuals was studied.

\section{Result and Discussion}

The first cenopopulation was studied along the Churuk-Jangeldy highway in thean altitude of $417 \mathrm{~m}$ above sea level. Geographical coordinates of the cenopopulation: N 40044.816 E 063040.229 . The soil of the described area is pebbly. The total projected grass cover is $22 \%$. The botanical composition of the community is relatively rich and it consists of 25 species of vascular plants. The plant community is dominated by Salsola arbuscula, Artemisia diffusa. The dominant species are Astragalus villosissimus, Ammothamnus lehmanii, Ferula foetida, Tulipa sogdiana, Carex physodes, etc (Table 1).

The second cenopopulation is described $18 \mathrm{~km}$ north of the Kyzylkum desert station along the Shafirkan-Jangeldi road as part of the ephemeral-ephemeroidsagebrush community. Geographical coordinates of the cenopopulation N 400 $77.718 \mathrm{E} 063058.843$, height $373 \mathrm{~m}$ above sea level. The soil of the described area is gravelly. The total projected grass cover is $21 \%$. The botanical composition of the communities consists of 34 species. The dominant community is Artemisia diffusa Krasch. ex Poljakov. Along with sagebrush, Astragalus ammotrophus Bunge, Ferula foetida (Bunge) Regel, Cousinia hammadae Juz., Astragalus villosisimus Bunge, etc. grow here (Table 1 ).

O. tavernierifolia Stocks ex Boiss.-annual squat plant, $3-7 \mathrm{~cm}$ tall. Almost stemless, the leaves on the upper side are covered with short pressed, and from below with long protruding white hairs, located on long (up to $5 \mathrm{~cm}$ ) petioles ending in a large lobe-leaf obovate. Peduncles $2-3.5 \mathrm{~cm}$ long. Brushes are loose, 3 - 7 flowered. Calyx 3-3. $5 \mathrm{~cm}$ long. The beans are wrinkly-cellular, about $1 \mathrm{~cm}$ long and wide. Blooms in May, bears fruit in June. Additionally, eight features of the allocation characteristic were analyzed: the number of seeds per individual, the total mass of one individual, the mass of roots, the mass of the aboveground vegetative part, the mass of the generative part, the mass of one seed, the height of the aboveground part, the length of the roots, and the vector spectrum was constructed.

The analysis of allocation polygrams showed that Onobrychis tavernierifolia has high indicators of the number of seeds ( 5 points) and the total mass of one individual (4 points), and less values are assigned to the height of the aboveground part of the individuals ( 2 points) and the length of the roots ( 2 points) (Figure 2).

Seed propagation is the most important stage in the life and development of plants, which ensures the preservation of the turnover (replacement) of generations and, thanks to passive movement, the settlement of populations. In this regard, seeds represent units of reproduction and settlement, means for experiencing unfavorable conditions, and are also a bank of genetic variants that are formed as a result of combinative variability. Seeds store information about the 
Table 1. Species composition and abundance of the $O$. tavernierfolia community.

\begin{tabular}{|c|c|c|c|c|}
\hline \multirow[t]{2}{*}{ № } & \multirow[t]{2}{*}{ Species } & \multirow[t]{2}{*}{ Life form } & \multicolumn{2}{|c|}{$\begin{array}{c}\text { Projective } \\
\text { coverplants, \% (CP) }\end{array}$} \\
\hline & & & $\mathrm{CP} 1$ & $\mathrm{CP} 2$ \\
\hline 1 & Salsola arbuscula Pall. & Shrub & 5 & 1 \\
\hline 2 & Astragalus villosissimus Bunge & Shrub & + & 1 \\
\hline 3 & Ammothamnus lehmanii Bunge & Shrub & + & - \\
\hline 4 & Artemisia diffusa Krasch.ex Poljakov & Semi-shrub & 7 & 5 \\
\hline 5 & Acanthophyllum stenostegium Freyn & Semi-shrub & - & 2 \\
\hline 6 & Calligonum zakirovii (Chalkoziev) & Shrub & + & - \\
\hline 7 & Astragalus ammotrophus Bunge & Perennial & - & 1 \\
\hline 8 & Cousinia hammadae Juz. & Perennial & - & + \\
\hline 9 & Ixiolirion tataricum (Pall.) Schult. \& Schult. fil & Perennial & - & + \\
\hline 10 & Ferula foetida (Bunge) Regel & Perennial & 2 & 2 \\
\hline 11 & Tulipa sogdiana Bunge & Perennial & 4 & - \\
\hline 12 & Carex physodes Bieb. & Perennial & 3 & 3 \\
\hline 13 & Peganumharmala L. & Perennial & & + \\
\hline 14 & Poa bulbosa L. & Perennial & + & \\
\hline 15 & Allium kyzylkumii Kamelin & Perennial & - & + \\
\hline 16 & Eremurus korolkowii Regel & Perennial & - & + \\
\hline 17 & Rhinopetalum karelinii Fisch.ex D. Don & Perennial & - & + \\
\hline 18 & Tulipa lehmanniana Merkl & Perennial & + & + \\
\hline 19 & Carex physodes Bieb. & Perennial & 3 & 3 \\
\hline 20 & Amberboa turanica Iljin & Annual & + & + \\
\hline 21 & Goldbachia laevigata (Bieb.) DC. & Annual & + & - \\
\hline 22 & Hypecoum parviflorum Kar et. Kir & Annual & + & - \\
\hline 23 & Nonea caspica (Willd.) G. Don & Annual & + & - \\
\hline 24 & Roemeria refracta (Stev.) DC & Annual & + & 1 \\
\hline 25 & Onobrychistavernierifolia Stocks ex Boiss & Annual & + & + \\
\hline 26 & Strigosella africana (L.) Boiss & Annual & + & + \\
\hline 27 & Anisantha tectorum $L$. & Annual & + & + \\
\hline 28 & Takhtajanianthapusilla (Pall.) Nazarova & Annual & - & + \\
\hline 29 & Koelpinia linearis Pall. & Annual & - & + \\
\hline 30 & Delphinium barbatum Bunge & Annual & - & + \\
\hline 32 & Strigosella grandiflora (Bunge) Botsch & Annual & - & + \\
\hline 32 & Ceratocephala testiculata (Crantz) Bess. & Annual & - & + \\
\hline 33 & Alyssum desertorum Stapf. & Annual & - & + \\
\hline 34 & Ziziphora tenior L. & Annual & - & + \\
\hline 35 & Stipa hohenackeriana Trin. \& Rupr & Annual & - & + \\
\hline 36 & Bromus danthoniae Trin. & Annual & - & + \\
\hline 37 & Amberboa turanica Iljin & Annual & - & + \\
\hline 38 & Cuminium setifolium (Boiss.) Koso-Pol. & Annual & - & + \\
\hline 39 & Ceratocephala falcata (L.) Pers. & Annual & + & 2 \\
\hline 40 & Astragalus remanens $\mathrm{Nabiev}$ & Annual & + & - \\
\hline 41 & Eremopyrum distans (C. Koch) Nevski & Annual & + & - \\
\hline 42 & Lallimanthia royleana (Benth.) Bent & Annual & + & + \\
\hline 43 & Holosteum polyganum C. Koch & Annual & + & - \\
\hline
\end{tabular}




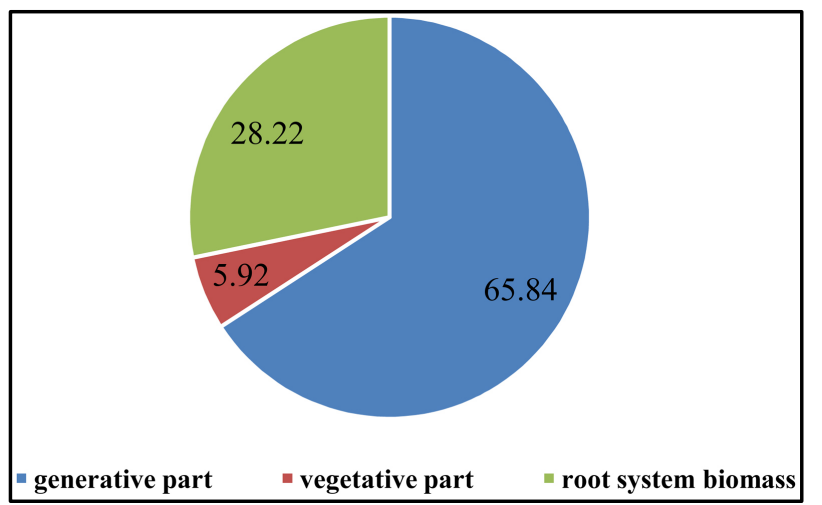

Figure 2. Allocation diagram of $O$. tavernierifolia.

principles of the system organization of the population and are able to recreate it under appropriate conditions). By Z. Shaniyazova [4], analysis of allocative signs in desert of ephemers are divided into four groups:

The first-with low values of the total biomass and seed production; the second-lowest value of the total biomass and average seed production; thirdly, medium or high values of the total biomass and high seed productivity, and a fourth having high or average values of the total biomass and low seed production (Figure 3; Table 2).

$O$. tavernierifolia belongs to the first group by the nature of allocation, characterized by low values of total biomass and low seed productivity (Table 3 ).

The density of ephemera populations can largely be determined by the amount of seed productivity, but it also depends on many parameters that characterize seeds as a special population group. For the permanent existence of desert annuals in the communities, the presence of a soil stock of seeds and the density of individuals is of particular importance.

At the sites, the soil stock of seeds was determined from a depth of $0-10 \mathrm{~cm}$ of soil. The maximum number of seeds of incoming seeds per year was noted in CP 2 (up to $9 \mathrm{pcs} / 1 \mathrm{~m}^{2}$ ). On CP 1 , this indicator is low $\left(3 \mathrm{pcs} / \mathrm{m}^{2}\right.$ ).

The density of $O$. tavernierifolia individuals at temporary sites in 2019 ranged from 0.9 to 2.5 individuals $/ \mathrm{m}^{2}$ and in 2020-0.1 - 3.3 $\mathrm{m}^{2}$ (Figure 4). Similar variation in the density of individuals according to $Z$. Shaniyazova [4] is due to the fact that the seeds of desert ephemera do not have a period of endogenous rest or this period is very short and the possibility of germination is mainly determined by the external situation. According to the density of individuals in the transects desert ephemera are divided into 5 groups [4]:

1) The highest density - units of individuals $/ \mathrm{m}^{2}$, presence in the active state; 2 ) The highest density is a unit of individuals $/ \mathrm{m}^{2}$, the presence is almost constant; 3) The highest density-tens of individuals $/ \mathrm{m}^{2}$, the presence of episodic; 4) The highest density-tens of individuals $/ \mathrm{m}^{2}$, the presence of constant; 5) The highest density is hundreds of individuals $/ \mathrm{m}^{2}$, the presence is almost constant.

According to this classification, $O$. tavernierifolia belongs to the second group: the highest density is a unit of individuals $/ \mathrm{m}^{2}$, the presence is almost constant. 


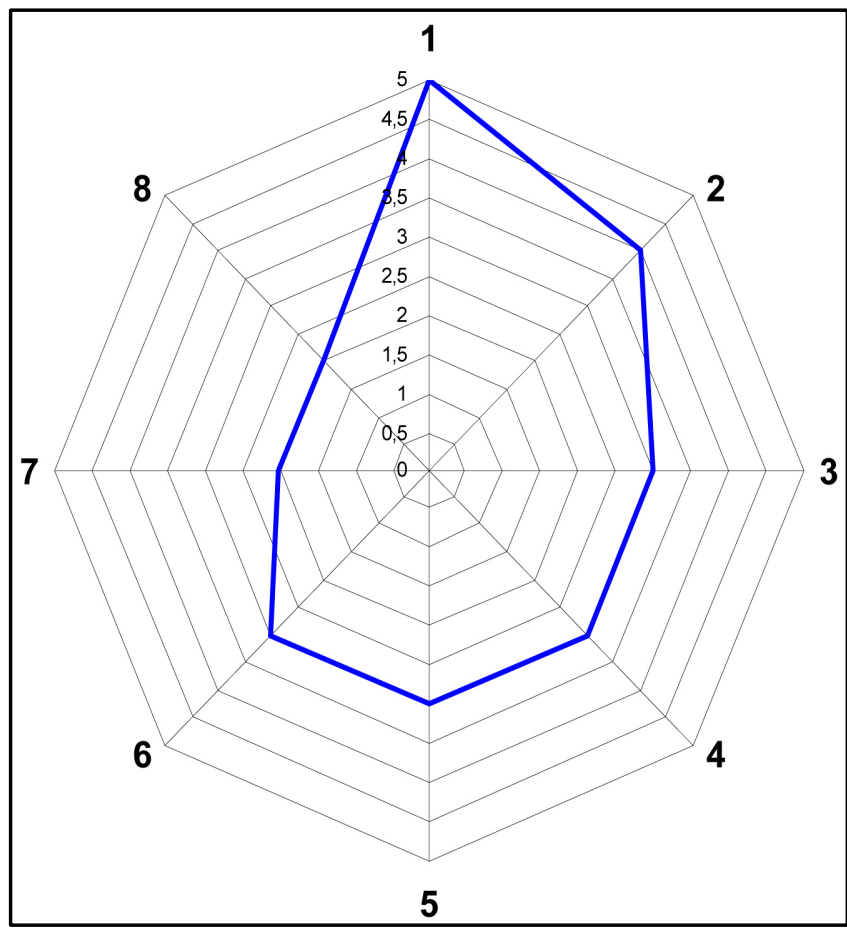

Figure 3. Vector polygram of $O$. tavernierifolia. Note: 1-the number of seeds, 2-the total mass of one individual, 3-the mass of the roots, 4 -the mass of the aboveground vegetative part, 5 -the mass of the generative part, 6-the mass of one seed, 7-the height of the aboveground part, 8 -the length of the roots.

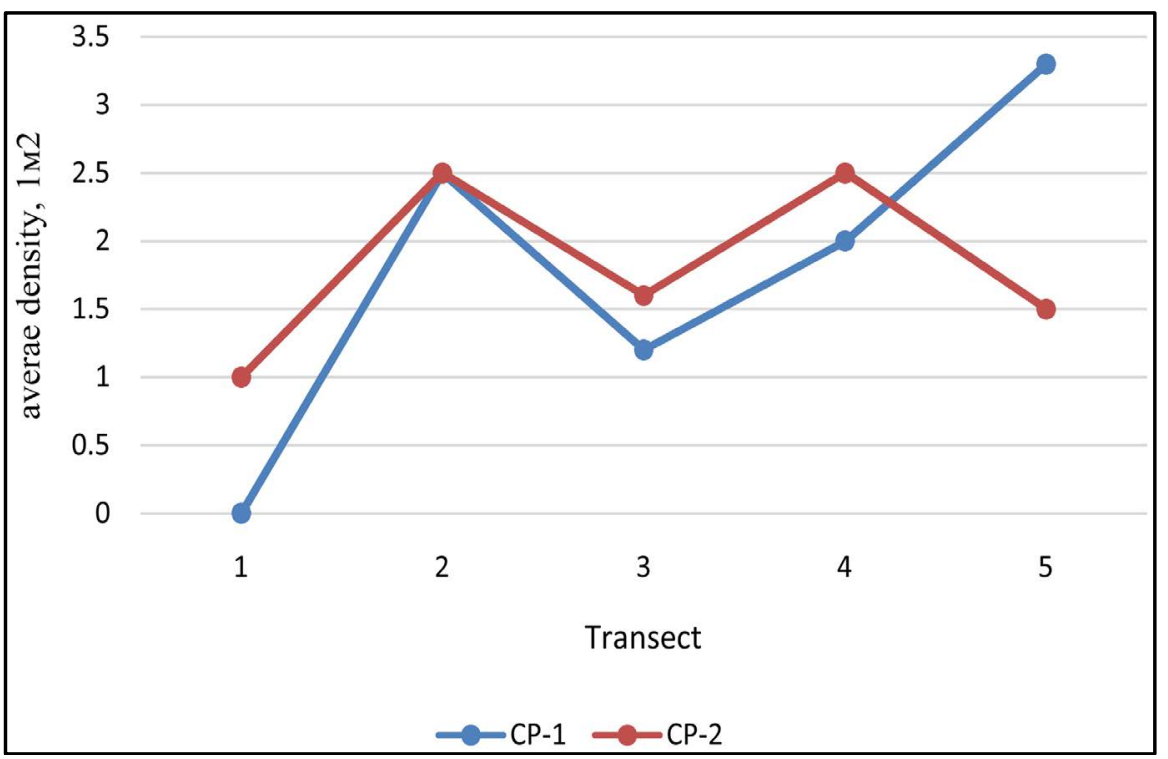

Figure 4. Density of O. tavernierifolia (transects).

O. tavernierifolia is characterized by low seed productivity and accordingly with minimal seed entry into the soil and low density of individuals in coenopopulations. During the years of the study regardless of weather conditions, O. tavernierifolia individuals were constantly present in the transects (Figure 4). 
Table 2. Population and organism parameters of O. tavernierifolia.

\begin{tabular}{|c|c|c|c|c|c|c|}
\hline \multirow{2}{*}{ № } & \multirow{2}{*}{ Signs } & \multicolumn{5}{|c|}{ Points } \\
\hline & & I & II & III & IV & $\mathrm{V}$ \\
\hline 1 & $\begin{array}{l}\text { The number of } \\
\text { seeds }\end{array}$ & $5-5.4$ & $5.5-5.8$ & $5.9-6.2$ & $6.3-6.6$ & $6.7-7$ \\
\hline 2 & $\begin{array}{l}\text { The total mass of } \\
\text { one individual. mg }\end{array}$ & $0.37-0.45$ & $0.46-0.54$ & $0.55-0.63$ & $0.63-0.72$ & $0.73-0.85$ \\
\hline 3 & $\begin{array}{l}\text { The mass of the } \\
\text { roots. mg }\end{array}$ & $0.018-0.025$ & $0.026-0.033$ & $0.034-0.041$ & $0.042-0.049$ & $0.050-0.057$ \\
\hline 4 & $\begin{array}{l}\text { Mass vegetative } \\
\text { part. mg }\end{array}$ & $0.22-0.27$ & $0.28-0.33$ & $0.34-0.39$ & $0.40-0.45$ & $0.46-0.51$ \\
\hline 5 & $\begin{array}{l}\text { Mass generative } \\
\text { part. g }\end{array}$ & $0.05-0.116$ & $0.007-0.183$ & $0.184-0.25$ & $0.26-0.326$ & $0.327-0.384$ \\
\hline 6 & $\begin{array}{l}\text { The mass of one } \\
\text { seed }\end{array}$ & $0.017-0.023$ & $0.024-0.031$ & $0.032-0.039$ & $0.040-0.045$ & $0.046-0.055$ \\
\hline 7 & $\begin{array}{l}\text { The height of the } \\
\text { aboveground part }\end{array}$ & $2.80-2.93$ & $2.94-3.01$ & $3.02-3.09$ & $3.10-3.17$ & $3.18-3.25$ \\
\hline 8 & $\begin{array}{l}\text { The length of the } \\
\text { roots. } \mathrm{cm}\end{array}$ & $8.3-8.8$ & $8.9-9.5$ & $9.6-10.2$ & $10.3-10.8$ & $10.9-11.3$ \\
\hline
\end{tabular}

Table 3. Seed productivity of $O$. tavernierifolia in transects.

\begin{tabular}{ccccc}
\hline \multirow{2}{*}{ Years } & \multicolumn{5}{c}{ Number of seeds per 1 individual } \\
\cline { 2 - 5 } & $\min$ & $\max$ & Average & The error is average. \\
\hline 2019 & 3 & 7 & 4.7 & 0.37 \\
2020 & 3 & 7 & 5.9 & 0.33 \\
\hline
\end{tabular}

\section{Conclusions}

In practice, with the modern study of the species population, the main strategy for the protection of rare species is to protect their habitats, i.e., the creation of protected areas is one of the most important areas of human nature protection. However, the last 10 years in the world have seen a doubling in the number and increase in the area of specially protected natural areas of more than 30 million $\mathrm{km}^{2}$. The results obtained from the evaluation of populations are used in carrying out monitoring studies for long years on rare plants. At the same time he used it as a material for local "Red books" [5] [6] [7].

The analysis of some indicators of $O$. tavernierifolia showed the following: having low values of total biomass and low seed productivity; the highest density is a unit of individuals $/ \mathrm{m}^{2}$ but the presence is almost constant. According to these characteristics $O$. tavernierifolia corresponds to the R-strategies and belongs to the group of tolerant species. The results obtained are used in plant protection.

\section{Acknowledgements}

The current research is done under the project PZ-20170919165 Inventory of 
rare and endangered species of vascular plants of Navoi and Bukhara regions.

\section{Conflicts of Interest}

The authors declare no conflicts of interest regarding the publication of this paper.

\section{References}

[1] Red Book of Uzbekistan (2019) Plants and Fungi. Chinor Publishing House, Tashkent.

[2] Korchagin, A.A. and Lavrenko, E.M. (1964) Field Geobotany. Methodological Guidelines. Moscow: Publishing House of the USSR Academy of Sciences, 3, 530.

[3] Markov, M.V. (1990) Population Biology of Rosette and Semi-Rosette Juvenile Plants. Russia, Kazan. Trud. 320 p.

[4] Shaniyazova, Z.P. (1994) Population Biology of the Ephemera of Karakalpakstan. Abstract Thesis of $\mathrm{PhD}$ (Biological Sciences). Russia, Moscow. $16 \mathrm{p}$.

[5] Abduraimov, O.S., Shomurodov, H.F. and Abduraimov, A.S. (2017) Distribution Pattern and State of Coenotic Population of Tulipa lehmanniana Merckl in Kyzylkum Desert Conditions (Uzbekistan). American Journal of Plant Sciences, 8, 288-296. https://doi.org/10.4236/ajps.2017.82020

[6] Abduraimov, O.S., Shomurodov, H.F. and Daniyarov, S.A. (2018) The Current State of Cenopopulation of Tulipa micheliana Hoog in Uzbekistan. American Journal of Plant Sciences, 9, 1725-1739. https://doi.org/10.4236/ajps.2018.98125

[7] Abduraimov, O.S., Shomurodov, H.F., Daniyarov, S.A., Mamatkasimov, O.T. and Teshaev, M.I. (2020) Distribution and Current State of Rare and Endangered Tulips (Liliaceae) Arid Zones of Uzbekistan. American Journal of Plant Sciences, 11, 736-744. https://doi.org/10.4236/ajps.2020.115053 